\title{
Furosemide 長期投与ラットの尿中
}

\author{
カルシウム排泄量・腎・副甲状腺
}

北海道大学医学部泌尿器科学教室 (主任：小柳知彦教授)

浅野 嘉文 野々村克也 小柳 知彦

\section{EFFECTS OF LONG TERM ADMINISTRATION OF FUROSEMIDE ON CALCIUM BALANCE, KIDNEY AND PARATHYROID GLAND}

\author{
Yoshifumi Asano, Katsuya Nonomura and Tomohiko Koyanagi \\ Department of Urology, Hokkaido University School of Medicine \\ (Director: Prof. T. Koyanagi)
}

Furosemide, a potent natriuretic agent, is well known to increase urinary calcium excretion. We study the effects of long term administration of furosemide on the calcium balance, renal function and histopathological changes of the kidneys and the parathyroid glands in the rat.

Furosemide $(20 \mathrm{mg} / \mathrm{kg}$ ) was administered 3-4 times per week for 62 weeks intraperitoneally in 10 male rats. The same volume of normal saline was administered intraperitoneally in 9 male rats as control. All were given with standard diet (CE-2) and deionized water. While urinary calcium and creatinine were measured every $1-4$ weeks, serum calcium and creatinine were measured in the first week and at the end of examination.

24 hours urinary excretion of calcium was elevated to two to three folds (a significant increase over the control: $\mathrm{p}<0.01$ ) after the furosemide loading, though serum calcium and creatinine levels remained as in control. Despite a marked hypercalciuria in the furosemide loaded rats, there was no evidence of stone formation in the kidney or in the urinary tract. On histopathological examination renal parenchyma showed some pyelonephritic changes but without evidence of crystal formation, while no significant change was noted in the parathyroid glands.

Based on these data we concluded that in our model, 1) there was a significant calcium loss in the absence of any change in the serum calcium, but 2) this hypercalciuria alone was not lithogenic, and 3) parathyroid glands showed no discernible secondary morphological changes.

Some disscussion was made on the possible mechanism of (a) failure in stome fomation, (b) lack of hyperplasia in the parathyroid glands, and (c) calcium homeostasis in the furosemide loaded rats.

Key words: furosemide, hypercalciuria

要旨：利尿剂である furosemide には尿中カルシウム排泄量を増やす作用もある．我々は，長期 furosemide 投与がカルシウムバランスや腎機能与える影響, さらに腎・副甲状腺の病理組織学的变化につ いて検討した。

実験動物には，4 週齢の WKA rat，雄を用いた，10匹に furosemide $20 \mathrm{mg} / \mathrm{kg}$ を隔日，62週腹腔内 投与，9匹を対照群とした。両群とも飼料はCE-2を, 飲水は脱イオン水を自由摂取させた。 $1 \sim 4$ 週毎 に24時間尿中カルシウム及びクレアチニン排泄量を測定，投与 1 週目と実駼終了時 (62週目) に採血し， 血清カルシウム及びクレアチニンを測定した。実験終了後屠殺し, 腎・副甲状腺の病理組織学的検索を 行なった。

24 時間カルシウム排泄量は, 対照群に比べ $2 \sim 3$ 倍に有意に増加したが, $(\mathrm{p}<0.01)$, 血清カルシウム・ クレアチニン值には差が見られなかった. Furosemide による高カルシウム尿症は確かに存在したが, 肉 眼的に腎一尿路に結石形成は見られなかった。病理組織学的にも結晶形成は認められなかったが，腎孟 
腎炎様変化が㵐漫性に見られた。しかし, 副甲状腺には過形成等の変化は見出せなかった. Furosemide により高カルシウム尿症を誘発することは可能であったが，これが病態的に renal hypercalciuria の実 験モデルとするには今回の実験結果からでは困難であった。ささら，結石形成が見られなかったことか ら, 高カルシウム尿症といら単独の要因では尿路結石の発症に至らないことが示唆された。

キーワード：フロセマイド, 高カルシゥム尿症

\section{緒言}

特発性高カルシウム尿症は, 原発性副甲状腺機能立 進症や尿細管性アシドーシスなど明らかな原因がなく 高カルシウム尿症が見られ, さらに血中カルシウム值 が正常のものを言う.Pak ら ${ }^{1)}$ はこれを, 腸管でのカル シウム吸収がえ進していることによる腸管型 (absorptive hypercalciuria) と, 腎でのカルシウム再吸収が低 下していることによる腎漏出型（renal hypercalciuria）に大きく分類している。ループ利尿剂である furosemide (Lasix $\left.{ }^{\circledR}\right)$ は主にヘンレ係蹄上行脚に作用し, ナトリウム・クロールの再吸収を阻害する2)31.さらに ヘンレ倸蹄において，カルシウム・マグネシウムの再 吸收も抑制する作用を持っている2)31. この尿中カルシ ウム排泄増加作用により，ヒト高カルシウム血症にお いて血中カルシウムを下げるのに有用とされている。 しかし一般に, 血中カルシウム值が正常な場合に furosemide を投与しても, 尿中カルシウム排泄量は増加 するが血中カルシウム值の変化は起きないと言われて (る⿱艹) 7). 以上のことから，この furosemide-induced hypercalciuria は, 特発性高カルシウム尿症のらち renal hypercalciuriaに類似した状態であるとされて (る34)(8)9). 高カルシウム尿症は尿路結石症の危険因子 の 1 つであるが，成人例で furosemide の長期投与で 尿路結石の形成をみたと言ら報告は見当たらない。 $\mathrm{Coe}^{4)}, \mathrm{Fujita}{ }^{6) 8}$ は投与期間が短いが健常人で furosemide-induced hypercalciuria の報告をしてい る.

これらのことから今回我々は, ラットを用いて furosemide を長期に投与することが尿中カルシウム排泄 量・血中カルシゥム值にどのような変化を与えるか, さらに腎及び副甲状腺に機能的・形態的变化を及ぼし 得るかを検討した。

\section{材料及び方法}

実験動物にはWister 系雄性ラットを使用し, furosemide $20 \mathrm{mg} / \mathrm{kg}$ を隔日腹腔内投与（ $\mathrm{L}$ 群 $: \mathrm{n}=10$ ), 対照群として生理食塩水 $2 \mathrm{ml} / \mathrm{kg}$ を隔日腹腔内投与し た (C 群: $n=9)$. 生後 4 週目より投与を開始し, 毎 週体重を測定し投与量を測定した。投与開始 $1 ， 2$,
$4,10,14,18,22,27,30,34,43,48,53,56$, 62 週目に, 代謝ヶージを使って個々の 24 時間尿を採取 した。 又, 投与開始 1 週目及び実験終了時に採血を行 なった。飼料は CE-2（日本クレア）を, 飲水は脱イオ ン水を自由摂取させた。

投与開始62週目に屠殺, 個々の両側腎及び副甲状腺 を摘出, 肉眼的観察の後ホルマリン固定しへマトキシ リン・エオジン染色 (HE染色)を行ない組織学的に検 索した。さらに, 腎に関してはvon Kossa 染色も行な い,カルシゥム結晶形成の有無も検討した。

個々の 24 時間尿はあらかじめ $6 \mathrm{~N}$ 塩酸 $(1 \mathrm{ml})$ をいれ たフラスコに蓄尿し, カルシウム及びクレアチニンを 測定, 血液は血清に分離しカルシウム及びクレアチニ ンを測定した。カルシウムはヤトロン社カルシウム測 定用試験液を使用し吸光度計にて, クレアチニンは AMES 社セラライザーにて測定した。なお, 統計学的 検討は student $\mathrm{t}$ 検定によって行なった.

\section{結 果}

1. 体重：L群において投与開始 4 週目からC 群に 比べて有意に軽くなり $(\mathrm{p}<0.01)$, 以後 $\mathrm{L}$ 群の体重は C 群の90～93\%とほぼ一定であった（図 1 )。

2. 24 時間尿量：L群において投与 1 週目より $13.8 \pm 0.9$ (mean $\pm \mathrm{SD}) \mathrm{ml} /$ day と C 群 の $8.17 \pm 1.6$

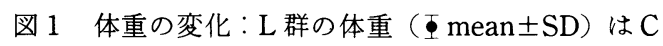
群 (\$ mean $\pm \mathrm{SD})$ に比べ 4 週以後有意に軽くなった $\left({ }^{*} \mathrm{p}<0.01\right)$.

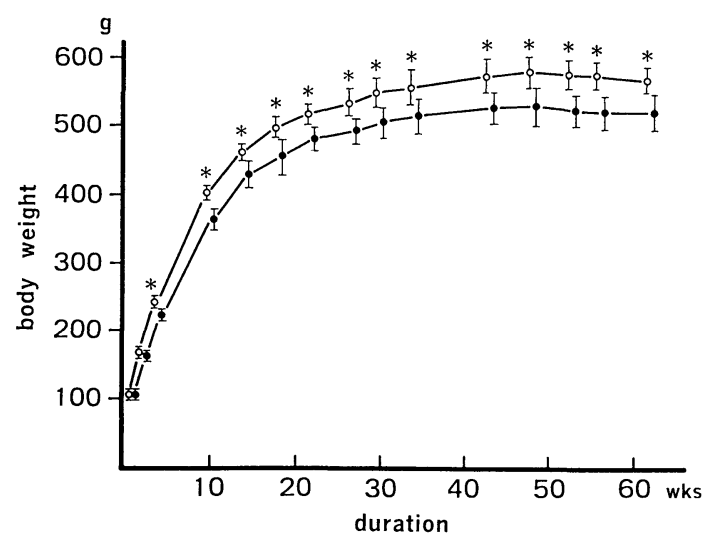


困 2 24時間尿量：L 群の尿量（甲mean士SD)は 1 週

目より C 群（すmean土SD）に比べ有意差増加した $(* \mathrm{p}<0.01)$.

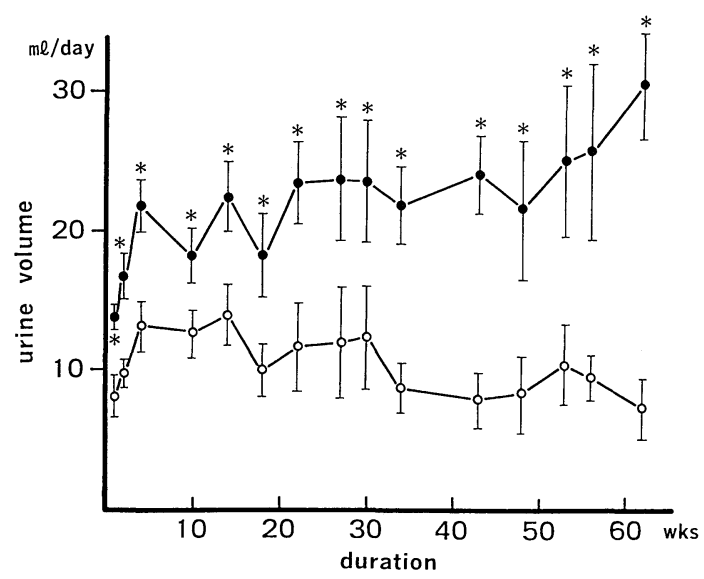

図 32 24時間尿中カルシウム排泄量：L 群の24時間尿

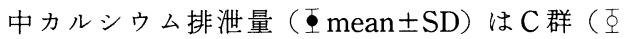
mean $\pm \mathrm{SD})$ に比べ, 1 週目及び14週以降有意に増加 した $\left({ }^{*} \mathrm{p}<0.01\right)$.

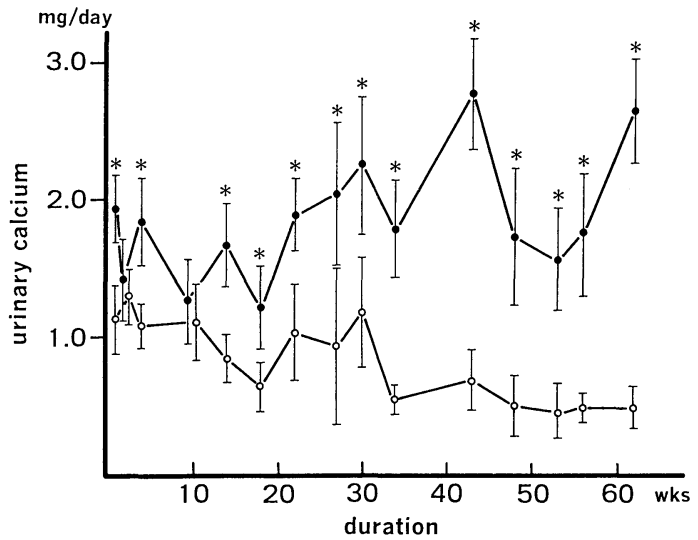

$\mathrm{ml} / \mathrm{day} に$ 比べ1.7倍と24時間尿量の有意な増加が認 められた $(\mathrm{p}<0.01)$. 以後 $\mathrm{L}$ 群 24 時間尿量は $20 \mathrm{ml} / \mathrm{day}$ 前後となり $\mathrm{C}$ 群の1.5〜 4.1倍（平均2.2倍）の尿量で あった（図 2 ).

3. 24 時間尿中カルシウム排泄量：L 群の 24 時間尿 中カルシウム排泄量は投与開始 1 週目 $1.93 \pm 0.25$ (mean士SD) $\mathrm{mg} /$ day と C 群の $1.14 \pm 0.27 \mathrm{mg} /$ day に 比べて有意に増加した $(\mathrm{p}<0.01) .2$ 週目は両群間に 有意差は見られなかった。 4 週目で L 群で1.7倍と再 度増加したが $(\mathrm{p}<0.01) ， 10$ 週目では有意差は見られ なかった．しかし，14週目以後では L 群において約 2 倍の排泄量となり，34週以後は 3 倍以上となった $(\mathrm{p}<$
図 4 24時間尿中クレアチニン排泄量：L 群の 24 時間 尿中クレアチニン排泄量 ( mean $\pm \mathrm{SD})$ に比べ減少傾向が見られた（*p< $\left.0.01,{ }^{* *} \mathrm{p}<0.05\right)$.

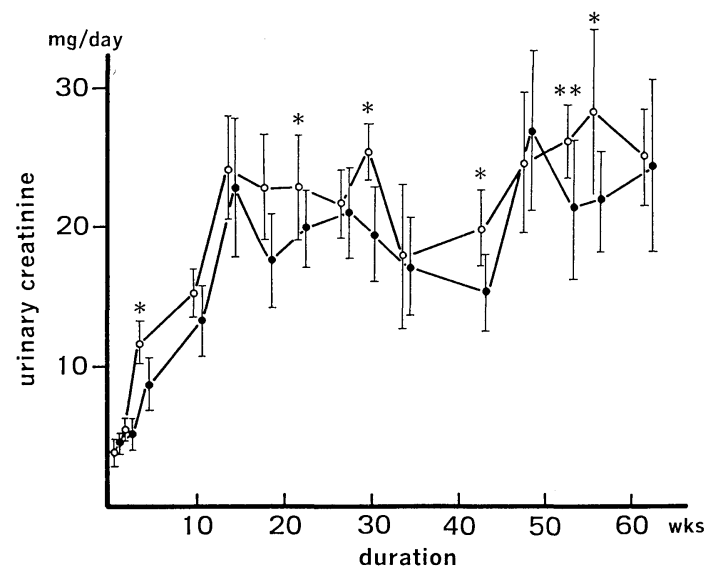

図 5 尿中カルシウム//クレアチニン比：L群の尿中 カルシウム/クレアチニン比 (すmean $\pm \mathrm{SD}$ ) は C 群

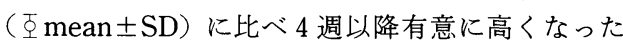
$\left({ }^{*} \mathrm{p}<0.01\right)$.

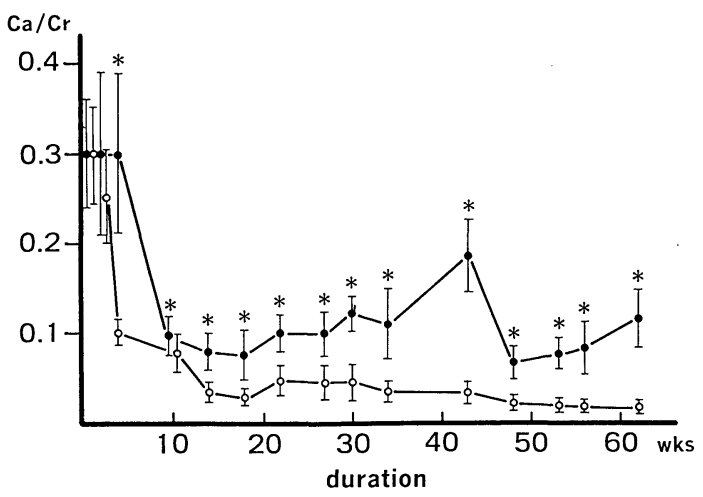

0.01 ) (図 3 ).

4. 24 時間尿中クレアチニン排泄量：L群の 24 時間 尿中クレアチニン排泄量は投与開始 2 週目より C 群 の75〜95\%と減少傾向が見られたが，有意差があった のは投与開始 $4 \cdot 22 \cdot 30 \cdot 44 \cdot 53 \cdot 56$ 週目のみであっ た $(\mathrm{p}<0.01, \mathrm{p}<0.05)$ (図 4 ).

5. 尿中カルシウム/クレアチニン比：投与開始 1 週 目及び 2 週目では両群間に有意差は見られなかった が， 4 週目以後 L 群に打いて尿中カルシウム/クレア チニン比は C 群に比べ平均3.3倍と有意に高くなった $(\mathrm{p}<0.01)$ (図 5 ).

6. 血清カルシウム値：投与 1 週目の值は, L 群で 
$8.53 \pm 1.36$ (mean \pm SD) $\mathrm{mg} / \mathrm{dl}, C$ 群 で $9.30 \pm 1.20$ $\mathrm{mg} / \mathrm{dl}$ と有意差はなく, 投与終了時も $\mathrm{L}$ 群 $11.2 \pm$ $0.8 \mathrm{mg} / \mathrm{C}$ 群 $11.0 \pm 0.6 \mathrm{mg} / \mathrm{dl}$ と有意差は見られなかっ た.

7. 血清クレアチニン值：投与 1 週目では L 群 $0.13 \pm 0.55$ (mean $\pm \mathrm{SD}) \mathrm{mg} / \mathrm{dl}, \mathrm{C}$ 群 $0.14 \pm 0.05 \mathrm{mg} /$ $\mathrm{dl}$, 投与終了時は L 群 $0.56 \pm 0.23 \mathrm{mg} / \mathrm{dl}, \mathrm{C}$ 群 $0.43 \pm$ $0.12 \mathrm{mg} / \mathrm{dl}$ といずれも両群間に有意差は見られな かった。

8. 腎重量：摘出した腎臓 1 個の重さは, L 群で $2.25 \pm 0.2($ mean $\pm \mathrm{SD}) \mathrm{g}, \mathrm{C}$ 群で $2.10 \pm 0.2 \mathrm{~g}$ と, L 群 が約 $7 \%$ 有意に重かった $(\mathrm{p}<0.01)$.

9. 肉眼的結石形成: 両群とも肉眼的に腎一尿管

図 6 L 群の腎 HE 染色標本 : 尿細管から集合管に散 在性にエオジン好性硝子様物質が甲状腺濾胞のよう に満たされている.

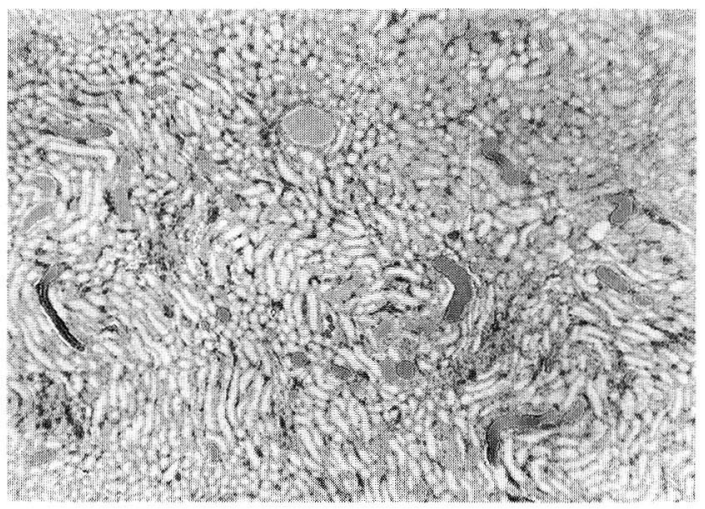

図 7 L 群の腎 $\mathrm{HE}$ 染色標本：系球体，尿細管・集合 管上皮には变化は見られない。

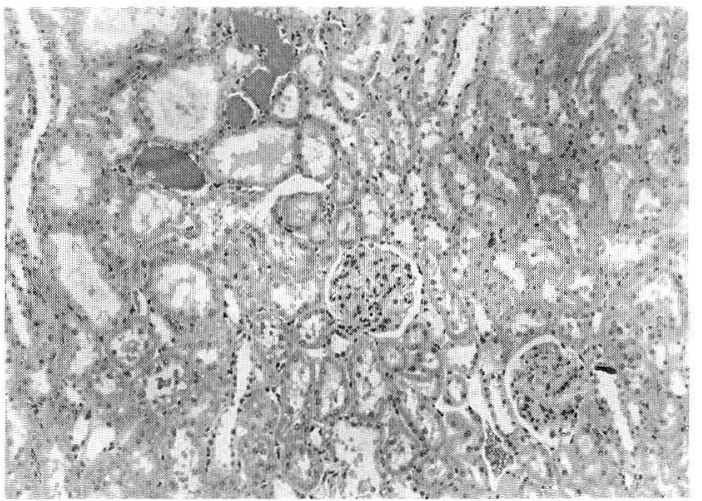

図 8 C 群の腎 $\mathrm{HE}$ 染色標本： $\mathrm{L}$ 群と同様に尿細管か ら集合管にエオシシン好性硝子様物質が甲状腺濾胞の よらに満たされているがその程度は軽度である。

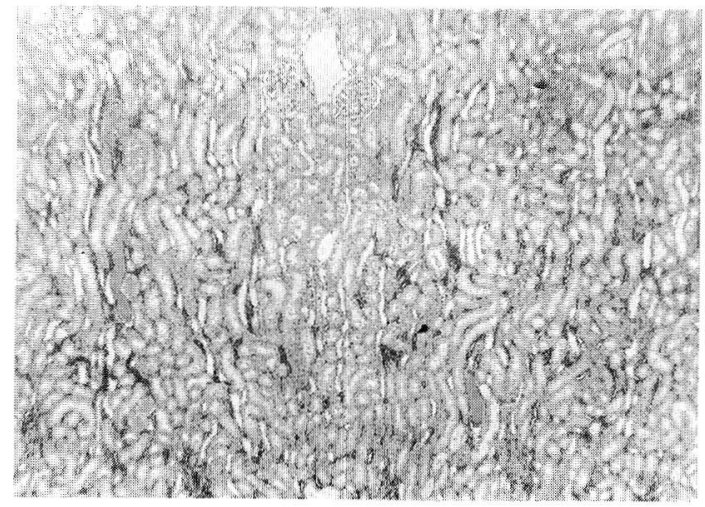

図 9 上皮小体の $\mathrm{HE}$ 染色標本(左 $\mathrm{C}$ 群, 右 $\mathrm{L}$ 群)：両群とも細胞構築の変化など見ら れない。
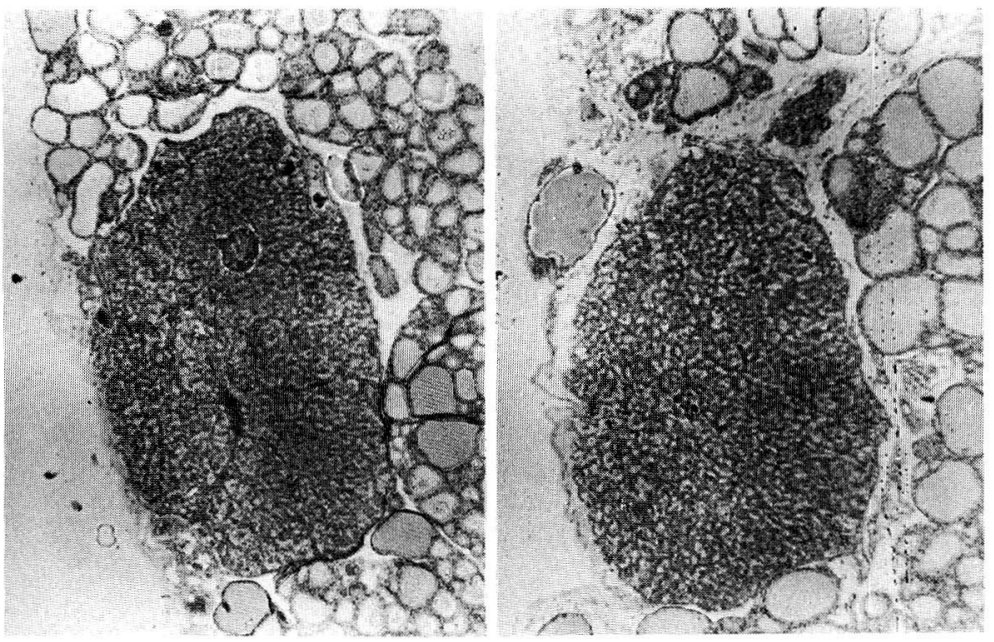
一膀胼に結石形成は見られなかった。

10. 腎の組織学的所見：図 6 は L 群の腎 HE 染色 標本であるが，尿細管〜集合管腔にエオジン好性の硝 子様物質が甲状腺濾胞のように満たされている。しか 乙，糸球体，尿細管・集合管上皮には変化は見られな かった（図 7 ）。同様の所見はC 群（図 8 ）でも軽度見 られた。しかし HE 染色及びvon Kossa 染色でも両群 とも明らかなカルシウム沈着や結石形成は見られな かった。

11. 副甲状腺の組織学的所見：ラットの副甲状腺 は, 甲状軟骨直下の気管の前面にある左右甲状腺の上 に左右 1 個ずつ位置している，肉眼的大きさに両群間 に差はみられず，又， $\mathrm{HE}$ 染色でも（図 9：左 C 群, 右 L 群）細胞構築の変化などは見られなかった。

\section{考察}

Furosemide $20 \mathrm{mg} / \mathrm{kg}$ 隔日腹腔内に投与したラッ ト群の尿中カルシウム排泄量は, 対照群に比べて 2 〜 3 倍に増加した。一方，血中カルシウム值は両群間 で有意差がみられなかった。このことは，尿中カルシ ウム排泄量の増加に対応して何らかの血中カルシウム 値を維持する機構が働いていることを推測するもので ある. Warshow ら ${ }^{10)}$ はラットに furosemideを25日間 投与し，尿量は $40 \sim 60 \%$ 上昇，尿中カルシウム排泄量 は 2 倍となったが, 血中カルシウム值は不変で あったことの説明として，腸管からのカルシウム吸収 がえ進することにより代償されているためであるとし た。さらに, Bushinsky ら ${ }^{11}$ は同様のラットを使用し た実験系で，通常の飼料では血中カルシウム值は正常 に保たれていたが，低カルシウム食にした群では血中 カルシウム值の低下をみたことから，Warshowらと 同様にカルシウムーバランスを保っている主役は腸管 からのカルシウム吸収六進であると言っている。また， Nielsen $5^{2)}$ \&, furosemideによる尿中カルシウム排 泄量増加によりきたしたカルシウムの負のバランス は，副甲状腺ホルモン（PTH）を介して是正されてい ると言っている。つまり，尿中カルシウム排泄量の増 加 $\rightarrow$ 血中カルシウム值の低下 $\rightarrow \mathrm{PTH}$ 分泌増加 $\rightarrow$ 腸管 でのカルシウム吸収旮進によりカルシウムーバランス が保たれていると考えられる。しなわち furosemideinduced hypercalciuria では二次性副甲状腺機能六進 の状態にあると言えよう。

腎機能の面では, 血清クレアチニン値のみであるが, 対照群と有意差がなかったことから, furosemideを長 期に大量投与 $(20 \mathrm{mg} / \mathrm{kg}) し て も$ 総腎機能そのものに
影響はないものと思われた. Brokaw ${ }^{12)}$ はカリウム欠乏 ラットにおいて腎肥大を見ると言っていることから， furosemide 投与群において腎重量が有意に増加して いたのは, furosemideによるカリウム欠乏が腎重量増 加の原因であったと思われた. 腎の組織学的検索にて, 尿細管〜集合管にエオジン好性の硝子様物質が充満さ れているのが見られた。こは対照群にも見られたが, より furosemide 投与群に著明であった。この変化は 細菌感染に基つく腎血腎炎に特徵的な所見とされてお り，カリウム欠乏ラットは腎感染に抵抗が弱いとも言 われており ${ }^{13) 14)}$, furosemideによるカリウム欠乏が腎 の感染を起こしやすくし，このような組織学的所見が 得られた可能性がある。

一方, 結石形成という面に関してみると, 肉眼的に, さらに病理組織的にも furosemide 投与のみでは尿路 結石の形成は見られなかった，尿路結石の大きな危険 因子の一つである高カルシウム疗症が存在していたに もかかわらず，今回の実験系で結石形成が見られな かったことから, 高カルシウム尿症単独では結石が形 成されない可能性があることが示唆された。

副甲状腺に関しても, 特発性高カルシウム尿症のう ち renal hypercalciuria では二次性副甲状腺機能立進 により副甲状腺に過形成が見られると言う報告9)15)が あるが，今回我々の実験系では病理組織学的には副甲 状腺に変化は見られなかった。ただ，ラットの副甲状 腺自体が非常に小さい臓器であることから大きさや重 量の測定が困難であったことや，組織学的にも単なる $\mathrm{HE}$ 染色では過形成は証明するのは困難で, 特殊組織 化学染色やより詳細な副甲状腺機能の検索が必要で あったと考えられる。

以上より, furosemide 長期投与は高カルシウム疗症 の実験モデルと成り得ると思われるが，いわゆる renal hypercalciuria の実験モデルとするには今回の 実験結果からでは困難であった。

\section{結 語}

ラットに furosemide $20 \mathrm{mg} / \mathrm{kg}$ を隔日・62週間腹腔 内投与し, furosemide-induced hypercalciuria につき 検討した. 康中カルシウム排泄量は対照群に比し 3 〜 4 倍に増えたが，血中カルシウム値に変化はなかっ た。これは二次性副甲状腺機能九進症により主に腸管 ではカルシウム吸収六進によりカルシウムーバランス が保たれていたためと思われた，Furosemideは高カ ルシウム尿症を誘発するのに利用できると思われた が, renal hypercalciuria の実験モデルとするには今 
回の実験結果からでは困難であった。ささに，結石形 成が見られなかったことから，高カルシウム尿症とい う単独の要因では尿路結石の発症に至らないことが示 唆された。

\section{文献}

1) Pak, C.Y.C.: Physiological basis for absorptive and renal hypercalciuria. Am. J. Physiol., 237, F415-F423, 1979.

2) Nielsen, S.P., Andersen, O. and Steven, K.E. : Magnesium and calcium metabolism during prolonged furosemide (Lasix ${ }^{\circledR}$ ) administration to normal rats. Acta Pharmacol. et Toxicol., 27, 469-479, 1969.

3) Weiner, I.M. and Mudge, H.M. : Diuretics and other agents employed in the mobilization of edema fluid. in The Phamacological Basis of Therapeutics. Gilman, A.G., Goodman, L.S., Rall, T.W. and Murad, F., 7th ed., p. 887-907, Macmillan Publisher Company, New York, 1985.

4) Coe, F.L., Cantabbury, J.M., Firpo, J.J. and Reiss, E. : Evidence of secondary hyperparathyroidism in idiopathic hypercalciria. J. Clin. Invest., 52, 134-142, 1973.

5) Toft, H. and Roin, J.: Effect of furosemide administration on calcium excretion. Brit. Med. J., 1, 437-438, 1971.

6) Fjita, T., Delea, C.S. and Bartter, F.C.: The effects of oral furosemide on the response of urinary excretion of cyclic adenosine monophosphate and phsphate to parathyroid extract in normal subjects. Nephron, 41, 333-336, 1985.

7) McElligott, M. : Effect of furosemide on serum calciumm. Ir. J. Med. Sci., 140, 410-412, 1971.

8) Fujita, T., Chan, J.C.M. and Bartter, F.C.: Effects of oral furosemide and solt loading on parathyroid function in normal subjects. Nephron, 38, 109-114, 1984.

9) Johansson, H., Thoren, L., Werner, I. and Grimelius, L. : Normocalcemic hyperpatathyroidism, kidney stones, and idiopathic hypercalciuria. Surgery, 77, 691-696, 1975.

10) Warshaw, B.L., Aanad, S.K., Kerian, A. and Lieberman, E.: The effect of chronic furosemide administration on urinary calcium excretion and calcium balance in growing rats. Pediat. Res., 14, 1118-1121, 1980.

11) Bushinsky, D.A., Favus, M.J. and Langman, C. B. : Mechanism of chronic hypercalciuria with furosemide ; increased calcium absorption. Am. J. Physiol., 251, F17-F24, 1986.

12) Brpkaw, A.: Renal hypertrophy and polydipsia in potassium-deficiet rats. Am. J. Physiol., 172, 333-346, 1953.

13) Fourman, P., McCance, R.A. and Parker, R.A. : Chronic renal disease in rats following a temporary deficiency of potassium. Brit. J. Exp. Path., 37, 40-43, 1956.

14) Woods, J.W., Welt, L.G., Hollander, W. and Newton, M.: Susceptibility of rats to experimental pyelonephritis following recovery from potassium depletion. J. Clin. invest., 39, 28-33, 1960.

15）中西正一郎：高カルシウム疗症の臨床的研究；カ ルシウム系結石患者における上皮小体機能六進 症。日泌尿会誌, 75, 1029-1037, 1984.

（1989年 7 月 25 日受理 